\title{
More than the Voice of the Caliphate: The Destructive Legacy of Abu Muhammad Al-Adnani
}

\author{
Anthony N. Celso \\ Professor, Department of Security Studies, Angelo State University
}

\begin{abstract}
The August 2016 killing of Abu Muhammad al-Adnani in a U.S. drone attack is an important step in degrading the Islamic State (IS). His symbolic and strategic importance as a propagandist and as an overseer of the caliphate's external terror operations cannot be doubted. Adnani was in the forefront in exhorting and directing IS operations to kill Westerners. The Paris, Brussels, Munich, San Bernardino, Orlando and Nice attacks can be linked to his impressive oratorical and organizational abilities. Adnani's September 2014 audio address urged IS supporters in North America and Europe to kill Westerners by any means possible. Adnani's propaganda express a Salafi-jihadist world view composed of three core principles al-wala' al-bara', jihad and takfir. This essay examines Adnani's propaganda messaging and his role in the caliphate's organization. First, it examines Adnani's audio addresses built around al-wala' al-bara', jihad and takfir. Second, it examines his role in the caliphate's external terror operations. Finally, it assesses the significance of his death.
\end{abstract}

Keywords: [Islamic Extremism] [Jihadism] [Caliphate] [terrorism]

\section{INTRODUCTION}

The August 2016 killing of Abu Muhammad al-Adnani in a U.S. drone attack is an important step in degrading the Islamic State (IS). His symbolic and strategic importance as a propagandist and as an overseer of the caliphate's external terror operations cannot be doubted. Adnani was in the forefront in exhorting and directing IS operations to kill Westerners. The Paris, Brussels, Munich, San Bernardino, Orlando and Nice attacks can be linked to his impressive oratorical and organizational abilities. Adnani's September 2014 audio address urged IS supporters in North America and Europe to kill Westerners by any means possible. ${ }^{1}$ The caliphate's sympathizers in the West obeyed his command often swearing allegiance to IS before or during their killings of Europeans, Canadians and Americans.

Adnani's official IS biography is written by Turki al-Binali the caliphate's most prominent ideologue and religious authority ${ }^{2}$ Binali is a fitting proponent of IS's ideology for he was a student of $\mathrm{Al}$ Qaeda theorist Abu Muhammad al-Maqdisi who like another Maqdisi student Abu Musab al-Zarqawi broke from his mentor. ${ }^{3}$ Binali represents the intergenerational gap between IS and Al Qaeda and how progressively the jihadist movement has radicalized. Binanli justifies IS' brutality by referencing $18^{\text {th }}$ and $19^{\text {th }}$ century Wahhabi rule in Saudi Arabia. ${ }^{4} \mathrm{He}$ is considered to be Adnani's likely successor. Binali tells us that Adnani was a committed religious student whose capacity to recite the Quran impressed all. This includes Abu Bakr al-Baghdadi the current leader of IS who was "moved" by Adnani's recitations.

Born in Syria Adnani was imprisoned by the Assad regime for his jihadist activities. He was one of the early members of Al Qaeda in Iraq (AQI) joining the organization soon after the 2003 US invasion. He swore fidelity [bay'ah] to AQI's emir Abu Musab al-Zarqawi. Binali informs us that Adnani played a critical role in the guidance of AQI's training camps. After being imprisoned by US authorities at Camp Bucca, Adnani was released by Iraqi officials after the US departure. His service to AQI led to senior positions in its Islamic State of Iraq (ISI) successor that in 2006 prematurely declared an emirate. Adnani swore loyalty to Zarqawi's successors including Abu Bakr al Baghdadi who in 2010 assumed leadership of the network. ISI's revitalized network capitalized on the power vacuum left by the US departure and the sectarian antagonisms percolating in the region. ${ }^{5}$

Adnani emerged as ISI's second in command and he played a pivotal role in the formation of its Syrian network. He along with Abu Muhammad al-Golani assisted in the creation of Jabhat al-Nusra 
(JN) that eventually broke away from IS and later Al Qaeda (AQ) to form Jabhat Fatah al-Sham [Levant Conquest Front]. ${ }^{6}$ His importance as a propagandist is incontrovertible for his prolific audio addresses pillory IS' many opponents that include "Zionist-Crusaders", Kurdish "apostates", the Shia, Alawites and Al Qaeda. He presents a didactic universe where IS aligned Sunnis confront a despotic world in which their struggle is divinely ordained to triumph over impossible odds. Significantly it is Adnani that declares the formation of the caliphate on June 19, 2014:
"We clarify to the Muslims that with this declaration of the khalafah, it is incumbent of all Muslims to pledge allegiance to the Khalifah Ibrahim and support him (may Allah preserve him). The legality of all emirates, groups, states, and organizations, becomes null by the expansion of the kalafaha's authority and the arrival of its troops in their areas."

Adnani's caliphate pronunciation was reaffirmed by Baghdadi (renamed Caliph Ibrahim) in his July 2014 Grand Mosque of Mosul sermon. Within the Muslim world this declaration was considered extraordinary and controversial. Not since the liquidation of the Ottoman Empire in 1924 by Kemal Ataturk's secular state, had there been a transnational Islamic state demanding the Muslim world's loyalty. Adding religious significance the declaration was made during the advent of Ramadan. ${ }^{8}$ With its authority spanning across the Iraqi-Syrian territorial divide, IS altered $19^{\text {th }}$ century era colonial borders.

The impact of this development cannot be overstated. IS' construction of a proto jihadist state altered the territorial integrity of two nations. Buttressing the caliphate's creation was the Iraqi army's collapse in June 2014 and IS' seizure of vast amounts of American supplied arms and its expropriation of bank accounts. With tens of thousands of well-armed fighters and vast financial network enriched by expropriations, taxation and illicit enterprise IS was a formidable force that by summer of 2014 threatened Baghdad and Iraqi Kurdistan.

Adnani's caliphate proclamation was rejected by most Muslims and proved controversial among jihadists. Though IS's predecessor was expelled from Al Qaeda's network for failing to heed its emir Ayman al-Zawahiri's directive to disband its Syrian network, Baghdadi's Mosul address intensified the intra-jihadist war between the two organizations. ${ }^{9}$ Central to the IS-AQ dispute is the legitimacy of Adnani's proclamation and Al Qaeda's assertion that its caliphate was unilaterally created without the consent of the jihadist movement. ${ }^{10}$

The controversy centers on the propriety of IS' shura [consultation] council ruling that its governing authority and its emir Baghdadi fit the necessary religious and political conditions to establish the caliphate. In his This is the Promise of Allah address Adnani argues that Islamic State has an obligation to declare such an entity and that Baghdadi's religious training and descent from the Prophet's tribe make him the ideal caliph. ${ }^{11}$ Having given its allegiance to Taliban leader Mullah Omar, Al Qaeda refused to swear fealty to Baghdadi's state and argued that AQI's prior bay'ah to its organization obligated its successor organization to abide by its command.

Restoring the caliphate is central goal of the global jihadist movement. It is seen as the means to combat the moral rot of jahiliyyah[ignorance of authentic Islam] and the military means to conquer the world. ${ }^{12}$ Jihadist theoreticians argue that Islam's incorporation of European secular influences have undone the divine stitching of Muslim religious order. Theological innovations [bidah] not based upon Quranic authority during the Modern era have, moreover, altered Islam's divine trajectory and stagnated its vitality. Having diminished the role of the Quran and hadith [statements and actions attributed to Muhammad] jihadists contend Islam has regressed toward jahiliyyah. Jihadi ideologues argue the decline of the Ottoman Empire and its collapse was due to these heterodox innovations. ${ }^{13}$

The Muslim world resurrection can, according to this narrative, proceed by returning to its original founding principles as practiced by Muhammad and his four righteous successors. By necessity this requires a transnational authority capable of purifying the Muslim world of apostasy and defending the ummah from external threats. Echoing this tradition Adnani's declares "So rush O Muslims and gather around your khalifah, so that you may return as you were once for ages, kings of the earth and knights of war."14

\section{MATERIALS AND MeTHODS}

Adnani's messaging is reinforced in its official English language magazines Dabiq and its successor Rumiyah that closely mirrors his ideas underscoring his significance. Rumiyah [Rome] venerates 
Adnani as a martyr who will be avenged. ${ }^{15}$ Adnani's speeches express a Salafi-jihadist world view composed of three core principles al-wala' al-bara', jihad and takfir. This essay has a tripartite structure. First, it examines Adnani's audio addresses built around al-wala' al-bara', jihad and takfir. Second, it examines his role in the caliphate's external terror operations. Finally, it assesses the significance of his death.

\section{RESULTS AND DISCUSSION}

Adnani's audio addresses propound key IS themes that the Muslim world is in a state of discord [fitna] and ignorance [jahiliyyah] that can only be overcome through fortification of medieval Islamic values. This crisis he contends is exacerbated by a Zionist-Crusader alliance with Iran that aims to annihilate righteous Sunnis who will join with IS in a final prophetic apocalyptic war. He depicts IS aligned Sunnis as facing a vast diabolical conspiracy. In That They Live By Proof he declares:

"The whole world has not come together to wage war against us except because we command the worship of Allah, alone without partner, and we incur others to do so. We make wala based upon it and we declare the disbelief of those who abandon it. We warn of shirk [polytheism] in the worship of Allah, and we are severe against it. We make enemies based upon it and we declare the disbelief of those engage in it. This is our call. This is our religion. For this alone, we fight the world and they fight us" 16

Al-wala' al-bala'[loyalty and disavowal]shapes Adnani's Sunni centric world view. This doctrine' separates a community of believers from what it views as a despotic world. ${ }^{17}$ It conveys a communal identity $[u m m a]$ governed by a shared faith that dissociates from the world. The doctrine divides the world between a sphere of virtuous belief and an outside order governed by wickedness. It seeks to create a community congruent with early Islamic practice whose virtuous ideal is Muhammad's Medina community.

By forming a spiritual refuge isolated from apostasy, jihadists aspire to expand their microcommunity that through violent conquest. Nelly Lahoud notesal-wala'wal-bara' is a key principle of the jihadist movement ${ }^{18}$. It is, moreover, an individualized concept for each jihadist can determine community's standards. This may explain rivalries within and the progressive radicalization of the jihadi movement for each jihadi has his standard of doctrinal purity. Taken as a collectivity Adnaniaudio declarations speak to a fanatical and paranoid Sunni centered perspective.

His 2011 address exhorts Sunni tribes to reject the US funded and armed Awakening Councils that badly degraded AQI between 2007-2010 as enforcers of a Crusader-Zionist plot to oppress Sunnis and empower the Shia.

"O, our people the Sunnis! O, you, the tribes of good! You have tried all regimes, and you have witness the treachery of all these parties and those failing perverted groups.

...You are invited to join hands with your sons, the mujahidin. To form a solid front against the Crusader-Rafidi plots and the Magi Iranian expansion in Mesopotamia and all Muslim lands; so as to restore your Islamic caliphate... "19

Though Adnani advocates Sunni interests it is clear that it represents a narrow subset excluding all coreligionists unaligned with Islamic State. He describes the Awakening Councils as "satanic sahawat" and he condemns Sunnis whose lack of religious virtue and opposition to IS make them diabolical traitors. ${ }^{20}$ Adnani's castigation of Sunni tribal leaders allied with Baghdad is reinforced by its 20112014 assassination campaign that killed hundreds of Awakening Movement members. ${ }^{21}$

The Islamic State's decimation of the Sons of Iraq Awakening militias plays a critical role in its shattering of the Iraqi's army's morale and facilitated IS' capture of much of North West Iraq. Adnani does, however, offer former Sunni opponents reconciliation and redemption to fortify its ranks. Despite its savage violence ISI did engage in tribal engagement with leaders willing to accept its authority. Where tribes refuse to swear bay'ah to Baghdadi they are annihilated.

As a guiding principle al-wala' al-bara' propensity for violence is rooted in early Islamic history. The Kharajites were so wedded to Muhammad's Medina ideal that they rebelled against his successors for their Quranic deviations. ${ }^{22}$ Their desire to create an ideal micro-culture led them to expel those whose faith they questioned. Early Islamic rule was often convulsed by internecine violence driven by doctrinal conflicts and power struggles. ${ }^{23}$

Al-wala'al- bara' lends itself to a takfirist world view. Jihadists sharply separate good and evil. Their demonization of the outside world propels them toward violent confrontation. Since jihadists view 
Muslim society as stricken by a post-Islamic ignorance [jahiliyyah] most co-religionists are apostates. ${ }^{24}$ Jihadists see these societies as gravely ill for they venerate man's law over God's rightful sovereignty (hakimiya). They view societal ignorance as so pronounced that that missionary preaching [da'wa] has little utility. With regimes so implacably vile jihadists only recourse is societal separation and rebellion.

If jihadists are to perform their divinely mandated mission to purify Islam they must resort to violence against regime supporters. Given theological prohibitions against murdering fellow Muslims, this requires co-religionists expiation from the faith. Historically takfir was practiced selectively against impious individuals subject to clerical adjudication. ${ }^{25}$

Over time, however, jihadists expanded takfir's scope. Some expiations are political (regime officials and their supporters) others sectarian [Shi'ites, Alawites and Druse) and some reflect intra-jihadist quarrels. The latter is seen in the fighting between the Islamic State and Al Qaeda. ${ }^{26}$ Takfirists often reference Ibn Taymiyyah medieval rulings on apostate Mongol Muslim rulers, Shi' ites, Alawites and Duse interpreting them broadly. ${ }^{27}$ Abu Musab al-Zaraqwi, for example, expanded Taymiyyah ruling that Shi' ite leaders should be killed into a sectarian genocidal campaign ${ }^{28}$ The Islamic State represents the crest of this progressive radicalization that can be seen in Adnani's discourse. He presents the Shia [rafidah] as apostates and devilsin league with a nefarious Zionist-Crusader world order and he describes their towns and villages are "nests of treachery" and "centers of filthiness". ${ }^{29}$

Resorting to takfirist excommunication legitimates killing Muslims. By preserving intra-community purity jihadists defend an authentic interpretation of the faith. This requires a strategy of offensive warfare [jihad] to (1) ensure the umma's protection and (2) expand the boundaries of its governance. Jihad and martyrdom are the centerpiece of IS' propaganda

Jihad's meaning invites controversy. ${ }^{30}$ Multiple interpretations engender complex doctrinal and definitional debates. Historically jihad involved personal struggle with one's faith (greater jihad) and defensive war against aggressors [lesser jihad]. Modern jihadists have expanded it to include aggressive warfare against apostates and their infidel masters. It is a strategy of expansive war that seeks the annihilation of all enemies. Accordingly Adnani's pleads:

"O, Allah. Support us against America and its allies of the Jews, Crusaders, Rafidah, atheists, groups, fronts, and apostate factions, and against the Nusayriyyah [Alawites] and their allies" 31

Jihadist doctrine seeks the creation of a pure Islamist micro-culture. Despite their opposition to the Islamic State's caliphate, Al Qaeda ideologues envision an emirate to lead the global jihadist struggle. Abu Bakr Naji, for example, advocates creating a nascent jihadist state from disorder and upheaval. ${ }^{32}$ Once implanted this micro-community would serve as an insurrectionary jihadist vanguard committed to regional destabilization.

Naji's book The Management of Savagery is viewed as the Islamic State's model for warfare and Sharia governance. ${ }^{33}$ In Dabiq first issue IS sketches Naji prescribed path to power falsely attributing his stages to Al Qaeda in Iraq (AQI) founder Abu Musab al-Zarqawi. ${ }^{34}$ The Islamic State sees its headquarters in Raqqa as its new Medina and its caliphate's governing blueprint. According to Aymen Jawad al-Tamimi Raqqa's administrate and judicial rulings have been extended throughout IS's IraqiSyrian wilaya [provinces]. ${ }^{35}$

What makes the Islamic State distinctive within the jihadist movement is its apocalyptic orientation. Such sentiments are relatively absent in Al Qaeda's discourse. Will McCant argues Osama bin Laden and Ayman al- Zawahiri sharply criticized ISI for its apocalyptic orientations. ${ }^{36}$ The Islamic State's envisions an apocalyptic war against Crusaders in Syria that where its predestined victory in the Syrian town of Dabiq will lead to its conquest of Rome. The caliphate's English language magazines echo this millenarian word view. ${ }^{37}$ Prior to the Islamic State only the $19^{\text {th }}$ century Sudanese Mahdiyyah defined itself as an apocalyptic jihadist movement. Within this eschatological context Adnani predicts:

"We will conquer your Rome, break your crosses, and enslave your women, by permission of Allah, the Exalted. This is His promise to us. He is glorified and he does not fail in His promise. If we do not reach it that time, than our children and grandchildren will reach it, and they will sell your sons and slaves at the slave market ${ }^{3,38}$.

Complementing his oratorical skills was his position within the Islamic States media and terror operations. Adnani reportedly oversaw production values and content for IS' execution videos of 
enemy soldiers, homosexuals, western hostages, sorcerers, adulterers and Christians. The theatrical punishments (burials, drownings, immolations, beheadings, fire squad, casting people off of tall buildings) graphically shown were designed to inspire fear and generate support from young jihadists attracted to IS'video game violence.

Featured in many videos are European rap artists whose hip hop messages are designed to recruit Western fighters. In his profile of thirty thousand Syrian foreign fighters Richard Barrett documents that vast majority of these fighters are young males who dominate in the ranks of the Islamic State soldiers. ${ }^{39}$ Among the five thousand European fighters French, Belgian and British nationals are prominently displayed in IS' videos including the late British executioner Mohammad Emwazi nicknamed Jihadi John and Abdelhamid Abaaoud the organizer of the November 2015 Paris attacks who would later die in a police raid. ${ }^{40}$

Adnani, moreover, directed IS external terror operations across the world. Based on testimony by a German IS defector Adnani screened European candidates trained in the caliphate's camps to carry out the Paris and Brussels assaults. ${ }^{41}$ French and Belgian fighters were especially enthusiastic about committing attacks against their home countries. The Brussels suburb of Molenbeek has been a den for IS recruitment and terror planning.

Working with French ideologue Fabien Clain and Belgian team organizer Abdelhamid Abaaoud foreign fighters were trained, guided and dispatched to Europe to sow chaos. ${ }^{42}$ Though some plots were disrupted; others succeeded spectacularly. The training these teams received increased the lethality of IS' terror campaign. The caliphate's external operations in November 2015 killed more than 130 people across four locations in Paris and in March 2016 over 30 people perished in Brussels when IS terrorists attacked a metro line and airport." IS operations in Turkey have prioritized the targeting of Kurds and areas inhabited by Westerners. Its attacks outside the Blue Mosque and Ataturk International Airport in Istanbul were designed to destroy the tourism industry.

Beyond directing teams to kill Westerners, Adnani hoped to inspire lone wolf and homegrown terrorists. Adani's incendiary style can be seen in the passage below that eerily foreshadows attacks by IS sympathizers. His September 2014 address urges IS follower to:

"If you kill a disbelieving American or European-especially the spiteful and filthy French-or an Australian, or a Canadian, or any other disbelievers from the disbelievers waging war, including the citizens of the countries they entered into a coalition against the Islamic State, then rely on Allah, and kill him in any manner or way however it may be. Smash his head with a rock, or slaughter him with a knife, or run over him with your car. " 43

Since Adnani's call over two dozen plots or attacks have been committed in the West by Islamic State sympathizers. Heeding his entreaty Europeans and North Americans have been stabbed, bombed, axed, shot, beheaded, and in the most lethal lone wolf attack a IS sympathizer in Nice ran over 86 Bastille Day spectators with a tanker truck. Significantly the vast majority of those killed or wounded have been civilians. Trains, parade grounds, concerts, restaurants, shops, night clubs have been attacked. Many of the attackers swore fidelity to IS before they committed their atrocities.

Though it is impossible to gauge Adnani exact influence (terrorists have complex motives and multiple allegiances) it is reasonable to assume that his exhortations had some impact. The frequency of IS attacks greatly eclipses Al Qaeda's post 9-11 assaults against the West suggesting that in Europe and North America the caliphate has many more supporters than Zawahiri's network. Al Qaeda's signature far enemy strategy of attacking the Western homeland has been appropriated by the Islamic State. The chart on the next page sketches IS directed and inspired attacks in the West.

Islamic State Directed or Inspired Attacks in the West

\begin{tabular}{|l|l|l|l|}
\hline $\begin{array}{l}\text { Date of } \\
\text { Attack }\end{array}$ & Location of Attack & Weapon Used in Attack & Killed and Wounded in the Attack \\
\hline May 2014 & $\begin{array}{l}\text { Jewish Museum in } \\
\text { Brussels, Belgium }\end{array}$ & Automatic Weapon & $\begin{array}{l}\text { Four People Killed by IS trained } \\
\text { terrorist who is later detained and in } \\
\text { France and extradited to Belgium }\end{array}$ \\
\hline June 2014 & $\begin{array}{l}\text { Endeavor Hills, } \\
\text { Australia }\end{array}$ & $\begin{array}{l}\text { Kno Counter-Terrorism Officials } \\
\text { stabbed by IS sympathizer who is } \\
\text { killed by Police }\end{array}$ \\
\hline October & Saint-Jean-sur- & Car & Two Soldiers Killed by IS sympathizer \\
\hline
\end{tabular}




\begin{tabular}{|c|c|c|c|}
\hline 2014 & Richelieu, Canada & & who runs over them and later detained \\
\hline $\begin{array}{l}\text { October } \\
2014\end{array}$ & Ottawa, Canada & Automatic weapon & $\begin{array}{l}\text { One soldier shot and killed and one } \\
\text { policeman wounded by IS lone wolf } \\
\text { who storms in Ottawa Parliament } \\
\text { building who is killed by police }\end{array}$ \\
\hline $\begin{array}{l}\text { October } \\
2014\end{array}$ & New York City & Hatchet & $\begin{array}{l}\text { One person wounded before IS } \\
\text { sympathizer killed by police }\end{array}$ \\
\hline $\begin{array}{l}\text { December } \\
2014\end{array}$ & Paris, France & Knife & $\begin{array}{l}\text { Three police wounded by IS } \\
\text { sympathizer who is killed by police } \\
\text { during the attack }\end{array}$ \\
\hline January 2015 & Paris, France & Automatic Weapon & $\begin{array}{l}\text { IS sympathizer takes people hostage at } \\
\text { a Kosher grocery store killing four } \\
\text { before being shot dead by police }\end{array}$ \\
\hline $\begin{array}{l}\text { February } \\
2015\end{array}$ & Copenhagen, Denmark & Automatic Weapon & $\begin{array}{l}\text { Attack at free speech event at a } \\
\text { synagogue leaves no fatalities. One } \\
\text { guard at a Jewish Cultural center later } \\
\text { is later killed by IS sympathizer }\end{array}$ \\
\hline May 2015 & $\begin{array}{l}\text { Garland, Texas Curtis } \\
\text { Cutwell Center }\end{array}$ & Automatic Weapons & $\begin{array}{l}\text { Two IS sympathizers are killed after } \\
\text { they attack a free speech event } \\
\text { featuring cartoons of the Prophet } \\
\text { Muhammad }\end{array}$ \\
\hline June 2015 & $\begin{array}{l}\text { Saint- } \\
\text { Quentin=Fallavier, } \\
\text { France }\end{array}$ & Knife and Car & $\begin{array}{l}\text { IS supporter beheads his employer and } \\
\text { tries to ram his car into a gas cylinder } \\
\text { outside a factory. Later detained and } \\
\text { commits suicide in prison }\end{array}$ \\
\hline August 2015 & Thalys Train Attack & $\begin{array}{l}\text { Automatic weapon and } \\
\text { pistol }\end{array}$ & $\begin{array}{l}\text { One passenger shot and wounded } \\
\text { before IS supporter subdued by three } \\
\text { passengers }\end{array}$ \\
\hline $\begin{array}{l}\text { November } \\
2015\end{array}$ & Paris, France & $\begin{array}{l}\text { Automatic Weapons, } \\
\text { Grenades, and Suicide } \\
\text { Explosive Vests }\end{array}$ & $\begin{array}{l}130 \text { killed and } 368 \text { wounded when IS } \\
\text { trained teams attack four different } \\
\text { locations }\end{array}$ \\
\hline $\begin{array}{l}\text { December } \\
2015\end{array}$ & $\begin{array}{l}\text { San } \text { Bernardino, } \\
\text { California }\end{array}$ & Automatic Weapons & $\begin{array}{l}\text { Two IS sympathizers kill } 14 \text { people } \\
\text { and wound } 24 \text { at office Christmas } \\
\text { party later killed by police }\end{array}$ \\
\hline March 2016 & Brussels, Belgium & $\begin{array}{l}\text { Automatic Weapons, } \\
\text { Bombs and Suicide } \\
\text { Vests }\end{array}$ & $\begin{array}{l}\text { Four IS terrorists kill } 32 \text { people and } \\
\text { wound } 340 \text { at attacks at the airport and } \\
\text { metro. Three of the suspect die in the } \\
\text { attack and one is later detained }\end{array}$ \\
\hline June 2016 & Orlando, Florida & Automatic Weapon & $\begin{array}{l}\text { IS supporter kills } 49 \text { people at gay } \\
\text { nightclub }\end{array}$ \\
\hline June 2016 & Paris, France & Knife & $\begin{array}{l}\text { IS sympathizer beheads French police } \\
\text { officer and his female companion in } \\
\text { their residence before being killed by } \\
\text { police }\end{array}$ \\
\hline July 2016 & Wurzburg, Germany & Axe & $\begin{array}{l}\text { Four train passengers wounded by axe } \\
\text { wielding IS supporter who is later } \\
\text { killed by police }\end{array}$ \\
\hline July 2016 & Ansbach, Germany & Bomb & $\begin{array}{l}\text { IS supporter blows himself up outside } \\
\text { an outdoors music concert injuring } 15 \\
\text { people }\end{array}$ \\
\hline July 2016 & $\begin{array}{l}\text { Saint-Etienne du- } \\
\text { Rouvray Church attack }\end{array}$ & Knife & $\begin{array}{l}\text { French priest beheaded and three } \\
\text { people wounded by two IS supporters } \\
\text { who are killed by police when they } \\
\text { storm the church }\end{array}$ \\
\hline July 2016 & Nice, France & 19 Ton Cargo Truck & $\begin{array}{l}\text { IS lone wolf drives over bystanders } \\
\text { watching a Bastille Day Parade killing } \\
86 \text { people and injuring } 434 \text { before } \\
\text { being shot dead by police }\end{array}$ \\
\hline August 2016 & Charleroi, Belgium & Machete & $\begin{array}{l}\text { Two police women wounded by IS } \\
\text { supporter who is killed by police }\end{array}$ \\
\hline
\end{tabular}

Source: Harleen Gambhir, "ISIS Campaign in Europe” March 25, 2016 Institute for the Study of War accessed at http://understandingwar.org/backgrounder/isis-campaign-europe-march-2016 


\section{Conclusion}

While it is premature to predict the caliphate's demise, there are signs that IS extremism is eroding its popularity. Declining popular support has been exacerbated by the coalition's relentless air campaign targeting the caliphate's military positions and finances. US military authorities estimate that 45,000 IS fighters have been killed and the caliphate has lost over forty percent of its Iraqi territory in Iraq and 20 percent of its Syrian holdings. ${ }^{44}$ Precision air strikes have targeted IS oil wells, natural gas facilities, transport tankers and banks crippling the caliphate financial base. By some estimates revenue from clandestine oil sales are down by some two-thirds. ${ }^{45}$ Buttressed by 5,000 US military advisors Iraqi security forces are recovering offensive capability.

The caliphate's military reversals between 2014-2016 at Mosul Dam, Amerli, Kobane, Tikrit, Palmira, Ramadi, and Falluja are notable. The jihadist state's twin capitals of Mosul and Raqqa are now threatened. The probable fall of Mosul comes after the embarrassing capture of the prophetic town of Dabiq by Turkish supported Free Syrian Army (FSA) rebels threatens to derail the caliphate's apocalyptic narrative. Kurdish, regime and international forces aligned against the caliphate has proven difficult to resist. Reports of IS defections and summary executions within the group suggests morale is low. With diminished resources to pay fighters and maintain services IS's administration is forced to raise taxation further eroding its support. Efforts by states to restrict foreign fighters from going to Syria and tighter control over the Turkish border deny the caliphate the means to replenish its shrinking forces. IS, however, has responded vigorously to these challenges. Its demise is anything but guaranteed.

Adnani's reign as IS's chief spokesman elicited contrasting assessments. His colorful language (he describes President Obama as a "mule of the Jews") no doubt was designed to inflame, provoke, amuse and generate support. ${ }^{46}$ Analysts often mocked Adnani grandiose style, Olympian confidence and hyperbolic language seeing it as delusional and fearful. ${ }^{47}$ These critiques underestimate his strategic role as a propagandist and director of IS media and terror operations.

Adnani's polemical skills and organizational acumen will be difficult to replace for a movement under extreme pressure. Significantly the US directed war against the caliphate has killed six of the seven of IS' originalshura council members. ${ }^{48}$ Adnani's death does not end the Islamic State that is likely to survive not as a government but as a global insurgent movement that has vastly eclipsed $\mathrm{Al}$ Qaeda ----, a fact that many terror analysts continue to resist. Perhaps foreshadowing his own demise Adnani's last audio address in May 2016 declared:
"Would you be victorious if you kill ash-Shishani, Abu Bakr, Abu Zayd, or Abum Amir? No! Indeed victory is the defeat of one's opponent. Or do you, O America, consider defeat to be the loss of a city or the loss of land? Were we defeated when we lost cities in Iraq and were in the desert without any city or land? And would we be defeated and you victorious if you were to take Mosul or Sirte or Raqqah or even take all of the cities and we were to return to our initial condition? Certainly not! True defeat is the loss of willpower and the desire to fight." 49

Adnani's warning suggests that the IS movement like its Al Qaeda progenitor will endure. ISI's 20122014 reconstitution fed off the sectarian and political antagonisms raging in Syria and Iraq. While the IS's state project is likely to be destroyed its remission to insurgency will guarantee its resilience. Neither the Syrian civil war nor the ethno-sectarian conflicts in Iraq show any sign of abating. Western forms of rationality mean nothing to jihadists who are content to build earthly gates of paradise. Barring that they are content to be gloriously martyred in the pursuit of their totalitarian utopian project. Though the Islamic State is far from defeated Adnani's killing is welcome news and a pointed reminder of the fate awaiting his successor.

\section{REFERENCES}

\footnotetext{
${ }^{1}$ Abu Muhammad al-Adnani ash-Shami, "Indeed Your Lord is Ever Watchful" September 9, 2014 accessed at http://triceratops.brynmawr.edu/dspace/bitstream/handle/10066/16495/ADN20140922.pdf

2 Abu Turki bin Mubarek al-Binali, "A Biography of IS Spokesman Abu Muhammad al-Adnani as-Shami” November 1, 2014 accessed at http://pietervanostaeyen.com/2014/11/02/a-biography-of-is-spokesman-abumuhammad-al-adani-as-shami
} 
${ }^{3}$ Cole Bunzel, “The Caliphate's Scholar-in-Arms” Jihadica July 23, 2014 accessed at http://www .isn.ethz.ch/ Digital-Library/Articles/Detail/?id=182205

${ }^{44}$ Ibid

${ }^{5}$ Ken Pollack (2013), "The Fall and Rise and Fall of Iraq" July 30, 2013 access at http://www.Brook ings.edu/research/papers/2013/07/30-fall-rise-fall-iraq-pollack.pdf

6 Abu Turki bin Mubarek al-Binali, ibid

7 Abu Muhammad al-Adnani, "This is the Promise of Allah" June 19, 2014 page 5 accessed at http://thesis.haverford.edu/dspace/bitstream/handle/10066/14242/ADN201140629.pdf

${ }^{8}$ Michael W. S. Ryan, "From Theory to Action: The Rationale behind the Re-establishment of the Caliphate" in Terrorism Monitor 12:15 8-11

${ }^{9}$ Aaron Zelin, The War Between ISIS and Al Qaeda for Supremacy of the Global Jihadist Movement Research Note 20 The Washington Institute for Near East Policy (June 2014) accessed at http://www. Washington institute.org /uploads/documents/pubs/researchnote_20_Zelin.pdf;

${ }^{10}$ Cole Bunzel, "From Paper State to Caliphate: The Ideology of the Islamic State" The Brookings Project with the Muslim World Analysis Paper No. 19 March 2015 accessed at http://www.brookings.edu / /media/research/files/papers/2015/03/ideology-of-the-islamic-state.pdf; Charles Lister, "The Jihadi Rivalry: the Islamic State challenges Al Qaeda" Brookings Doha Center Analysis Paper No. 16 January 2016 accessed at http://www.brookings,edu / / /media/Research/ Files/Papers/2016/01/27-the-islamic-state-challenges-alqaeda.pdf

${ }^{11}$ Abu Muhamad al-Adnani "This is the Promise of Allah" ibid

${ }^{12}$ WalidPhares, The War of Ideas: Jihadism against Democracy (Palgrave McMillan: New York, 2008) 30,32

${ }^{13}$ Ibid

${ }^{14}$ Abu Muhammad al-Adnani, "The State of Islam Will Remain Safe" August 7, 2011 page 8 accessed at http://triceratops.brynmawr.edu/dspace/bitstream/handle/10066/15267/ADN20110807.pdf

${ }^{15}$ The Return of the KhalifaDabiq 1http://www.jihadology.net/2014/07/05/al\%e\%68\%sayat-media-centerpresents-a-new-issue-of-the-islamic-state-magazine-dabiq1/

16 Abu Muhammad al-Adnani "That They Live by Proof" page 7accessed at http://pietervanostaeyen. files. wordpresss.com

${ }^{17}$ NellyLahoud, Jhadis Path to Self-Destruction (C Hurst and Company: London, 2010)

${ }^{18}$ Ibid. 49-56

${ }^{19}$ Abu Muhammad al-Adnani, "The State of Islam Will Remain Safe”, ibid page 8

${ }^{20}$ Ibid page 9

${ }^{21}$ Jessica D. Lewis, “AQI's Soldiers Harvest Campaign:” Institute for the Study of War Backgrounder October 9, 2013 accessed at: http://understandingwar.org/sites/default/ files/Backgrounder Soldiers Harvest.pdf

${ }^{22}$ Ibid, 57-96

${ }^{23}$ Ephraim Karsh,Islamic Imperialism (Yale University Press: 2006) 10-43

${ }^{24}$ John Calvert, SayyidQub and the Roots of Radical Islam (Columbia University Press: New York, 2010)

${ }^{25}$ Mehdi Mozaffar, "What is Islamism: History and Definition of a Concept" Totalitarian Movements and Political Religions, Vol. 8, No. 1, March 2007, pgs. 17-33.

${ }^{26}$ Aaron Zelin, The War Between ISIS and Al Qaeda for Supremacy of the Global Jihadist Movement Research Note 20 The Washington Institute for Near East Policy (June 2014) accessed at http:// www.washington institute.org /uploads/documents/pubs/researchnote_20_Zelin.pdf

${ }^{27}$ M. CherifBassiouni," Evolving Approaches to Jihad: From Self-Defense to Regime Chang Political Violence" Chicago Journal of International Law 8:1 ; NaserGhabadzeh and Sharam A. Kbarzadea, "Sectarianism and the Prevalence of "othering" in Islamic Thought" Third World Journal 36:4 691-704; Hassam S. Timoni, "The Islamic Context of Global Jihadism : Why Ibn Taymiyyah Matters? I Chapter 3 in Lori Underwood (ed), The Root of All Evil: Religious Perspectives on Terrorism (Terrorism Studies: New York, 2013)

${ }^{28}$ NibrasKazimi, Syria through Jihadist Eyes (Hoover Institution; Stanford, 2010)

${ }^{29}$ Abu Muhammad al-Adnani, The State of Islam Will Remain Safe" ibid

${ }^{30}$ Assar Moghadan, "Salafi Jihad as a Religious Ideology” CTC Journal, (February 2008) Vol. 1, Issue 3;

${ }^{31}$ Abu Muhammad al-Adnani, "That they Live by Proof” ibid page 13

${ }^{32}$ Abu Bakr Naji, Management of Savagery available at http://www.vcfia.harvard.edu/olin/images/ management $\% 20$ of\%savagery\%20\%2005-23-2006.pdf

${ }^{33}$ Michael W.S. Ryan, "ISIS and Al Qaeda: Tactical Twins, Strategic Enemies” Terrorism Monitor 13:24 21-24 
34"From Hijrah to Khalafah" in Dabiq 1 The Return of the Khalifahal-Hayat Media Center accessed at http://www.jihadology.net/2014/07/05/a1\%e\%68\%sayat-media-center-presents-a-new-issue-of-the-islamic-statemagazine-dabiq1/ 34-40

${ }^{35}$ Aymen Jawad al-Tamimi,'The Islamic State's Educational Regulations in Raqqa" August 28, 2014 Aymenn Jawad al-Tamimi Blog accessed at http://www.aymennjawad.org/2014/08/the-islamic-state-educationalregulations-in-raqqa.

${ }^{36}$ William McCants, ISIS Apocalypse: the History, Strategy and Doomsday Vision of the Islamic State(Palgrave McMillian Trade: New York, 2015) Kindle version

37 Michael W.S. Ryan, "Dabiq: What the Islamic State's New Magazine Tells us about Their Strategic Direction. Recruitment Patterns and Guerilla Doctrine", Jamestown Terrorism Monitor accessed at http://www. jamestown.org/tm; Anthony Celso, "Dabiq IS's Apocalyptic 21 ${ }^{\text {st }}$ Century Jihadist Manifesto" Journal of Political Science and Public Affairs 2:4 doi: 10.4172/2332-0761.1000e111

${ }^{38}$ Abu Muhammad al-Adnani, "Indeed Your Lord Is Ever Watchful” ibid p5

${ }^{39}$ Richard Barrett, 'Foreign Fighters: An Updated Assessment of the Flow of Foreign Fighters into Syria and Iraq The Soufan Group December 2015 accessed at http://www.soufangroup.com/wp-content/uploads/2015/12/ TSG_ForeignFightersUpdate3.pdf

${ }^{40}$ Matthew Levitt, The Islamic State's Lone Wolf Era is Over" March 24, 2016 accessed at http:// www. washingtoninstitute.org/policy-analysis/view/the-islamic-sttaes-lone-wolf-era-is-over

${ }^{41}$ Florian Flade, The Islamic State Threat to Germany: Evidence from the Investigations" CTC Sentinel 9:7 1114; Sayed HuzaifahAlkaff and Muhammad Haziq Bin Jani, The Death of IS Top Strategist: Reflections on Counter-Terrorism Efforts" Counter Terrorist Trends and Analysis 8:9 4-9

${ }^{42}$ DaveedGartenstien-Ross and Nathaniel Barr,[Hot Issue] "Recent Attacks Illuminate the Islamic State's Europe Attack Network" Jamestown Foundation April 27, 2016 accessed at http:/ / Jamestown .org / program/hot-issuerecent-attacks-illuminate-the-islamic-states-attack-network-in-europe

${ }^{43}$ Abu Muhammad al-Adnani, "Indeed Your Lord is Ever Watchful” ibid page 11

${ }^{44}$ Samuel Osborne, "The US has killed 15,000 ISIS fighters for eve4ry American soldier ISIS has killed" The Independent September 5, 2016 accessed at http://www.independnet.co.uk/ news/world/ middle-east/isisislamic-state-us-soldiers-how-many-deaths-killed-iraq-syria; Tiffany Harness and LarisKarklis, "The Islamic State has lost this much territory in Iraq and Syria this year" June 10, 2016 accessed at http://www.washingtonpost.com/ news/worldviews/wp/2016/06/Islamic-state-has-lost-this-much-territory-inIraq-Syria-this-year

45 Matthew Levitt, "Countering ISIL Financing: A Realistic Assessment” February 2, 2015 accessed at http://www. washingtoninstitute.org/ uploads/documents/Levitt statement/20150502v.3.pdf

${ }^{46}$ Abu Muhammad al-Adnani, Indeed Your Lord Is Ever Watchful”, ibid page 5

47 Paul Kamolnick, Abu Muhammad al-Adnani May 26, 2016 Speech: More Evidence for Extreme Marginalization, Implosion and the Islamic State's Certain Future as a Hunted Underground Ultra-Takfiri Terrorist Criminal Entity Small Wars Journal July 2, 2016 accessed at http:// small wars journal.com/jrnl/art/abu-muhammad-al-adnani-may-21-2016-speech; David Milton and Muhammad al-Ubayd, “Adanani's Paradox: Projecting Strength While Feeling Fear CTC Perspectives October 16, 2016 accessed at

48 "Who rules (now) in the ISIS" September 5, 2016 accessed at http://archeyworldys.com/who-rules-now-inthe-isis/

${ }^{49}$ Abu Muhammad al-Adnani, "That They Live By Proof” page 5 